\title{
EFFECT OF FIRE ON MIXED-GRASS PLANT \\ COMMUNITIES IN BADLANDS NATIONAL PARK
}

\author{
Steven G. Whisenant \\ Botany and Range Science \\ Brigham Young University \\ Provo, UT \\ and \\ Dan W. Uresk \\ Rocky Mountain Forest \& Range Experiment Station \\ Rapid City, SD
}

\section{Objectives}

This research has the objective of determining the influence of fire on density and peak standing crop of the major grass species of the Badlands National Park mixed-grass prairie. An important goal is to evaluate the potential of prescribed fire for the control of Japanese brome (Bromus japonicus).

\section{Study Area and Methods}

This study was conducted on a mixed-grass prairie of the Badlands National Park in western South Dakota. Western wheatgrass was the dominant perennial plant species and Japanese brome was the codominant on the study area. Western wheatgrass tiller densities were rather consistent on untreated plots throughout the study.

Thirty 5- by 5-m plots were established in a randomized complete block design with 3 replications and 10 treatments. Treatments established were: untreated; burned, April 1983; burned, May 1983; burned, April 1983 and 1984; burned, May 1983 and 1984; clipped, April 1983; clipped, May 1983; atrazine application (1.1 kg a.i./ha), September 1983; burned, April 1983 and atrazine application, September 1983; and burned, April 1984.

Tiller densities were determined in April and July of 1983, 1984, and 1985 using five placements of an $0.10 \mathrm{~m}^{2}$ quadrat placed on a permanently marked diagonal across each plot. Differences in tiller density among treatments were determined with analysis of variance. Standing crops were determined in July 1983, 1984, and 1985 using five placements of an $0.10 \mathrm{~m}^{2}$ quadrat in each plot. Differences in standing crops among treatments were determined with analysis of variance. Orthogonal comparisons were made on nine previously selected contrasts.

The number of developed seeds per spikelet and per plant were determined in July 1983, 1984, and 1985. Seed production per $\mathrm{m}^{2}$ was determined by 
multiplying seed production per plant times the number of plants per $\mathrm{m}^{2}$. The Japanese brome seed reservoirs were determined by collecting the surface litter and the top $3 \mathrm{~cm}$ of soil in three $0.10 \mathrm{~m}^{2}$ quadrats from each plot. Mature and filled seeds were counted in each of these collections. Treatment differences were determined with analysis of variance at the $5 \%$ level of significance. Mean separations, when necessary, were conducted using Student-New man-Keul's test.

\section{Results and Discussion}

Japanese brome tiller density and standing crop were significantly $(P<0.05)$ reduced during the first year following either burning or atrazine application (Tables 1 and 2 ). However, during the second year, both tiller density and standing crop increased to preburn levels. Burning resulted in greater reductions in Japanese brome densities for at least two years following treatment than did clipping. This indicated that mortality resulted from the effects of heat rather than simply foliage removal. Atrazine applied as a preemergent herbicide significantly reduced Japanese brome tiller density and standing crop compared to the untreated plots (Tables 1 and 2).

The 1985 growing season was unusually dry and Japanese brome seed germination was very low. This confounded interpretation of treatment responses. However, it was apparent that all of the previously burned plots had reduced Japanese brome densities. This reduction was probably a result of more xeric microenvironments created by the loss of surface litter following fires.

Burning significantly increased western wheatgrass tiller density during the first growing season (Tables 1 and 2). However, during the second growing season, tiller density was reduced to untreated levels. Atrazine treatments significantly reduced western wheatgrass tiller density for the first year after application. Western wheatgrass standing crop was not significantly affected in 1983 or 1984 by any of the treatments (Table 2). However, in 1985, western wheatgrass standing crops were significantly increased on the 1984 burned plots and the atrazine applications.

Spring burning significantly reduced Japanese brome seed production during the first two years after burning (Table 3) and was still significantly reduced in the second season after burning. The dry 1985 growing season greatly reduced standing crops on all treatments. Seed production in 1985 was greatest on the untreated plots (T'able 3). Spring burning dramatically reduced the surface seed bank during the first two years after a fire (Table 3). The soil seed bank was not significantly affected during the first two years after burning in 1983. The reduced seed production in 1985 reduced the soil seed bank on all plots, with the greatest reductions occurring on previously burned plots.

\section{Conclusions}

Spring burning reduced Japanese brome density and standing crop for only one year. Western wheatgrass benefited from the Japanese brome reduction but was reduced to preburn levels in the following season if sufficient precipitation 
Table 1. Tiller densities (per $\mathrm{m}^{2}$ ) of Japanese brome and western wheatgrass in July 1983, 1984 and 1985, after treating in 1983 and/or 1984. Badlands National Park, South Dakota.

\begin{tabular}{|c|c|c|c|c|c|c|}
\hline \multirow[b]{2}{*}{ Contrast } & \multicolumn{3}{|c|}{ Japanese brome } & \multicolumn{3}{|c|}{ Western wheatgrass } \\
\hline & 1983 & 1984 & 1985 & 1983 & 1984 & 1985 \\
\hline $\begin{array}{l}\text { No treatment vs. } \\
1983 \text { burning }\end{array}$ & $\begin{array}{l}2,360 \\
908^{\star *}\end{array}$ & $\begin{array}{l}2,617 \\
2,028^{N S}\end{array}$ & $\begin{array}{l}306 \\
213^{*}\end{array}$ & $\begin{array}{l}295 \\
427\end{array}$ & $\begin{array}{l}375 \\
264^{N S}\end{array}$ & $\begin{array}{l}222 \\
149\end{array}$ \\
\hline $\begin{array}{l}\text { No treatment vs. } \\
1984 \text { burning }\end{array}$ & - & $\frac{2,617}{23}$ ** & $\begin{array}{l}306_{* *} \\
14\end{array}$ & -- & $\begin{array}{l}375 \\
507\end{array}$ & $\begin{array}{l}222 \\
299^{N S}\end{array}$ \\
\hline $\begin{array}{l}\text { No treatment vs. } \\
\text { double burning } \\
\text { (1983 and 1984) }\end{array}$ & -- & $\begin{array}{l}2,617 \\
580\end{array}$ & $\begin{array}{c}306 \\
81\end{array}$ & $\cdots$ & $333^{375} \mathrm{NS}$ & $\begin{array}{l}222 \\
153\end{array}$ \\
\hline $\begin{array}{l}1984 \text { burning vs. } \\
\text { double burning } \\
\text { (1983 and 1984) }\end{array}$ & $\cdots$ & $580^{23 *}$ & $8^{14} \mathrm{NS}$ & - & $\begin{array}{l}507 \\
333^{N S}\end{array}$ & $\begin{array}{l}299 * \\
153\end{array}$ \\
\hline $\begin{array}{l}\text { No treatment vs. } \\
\text { Atrazine } \\
\text { (Sept. 1983) }\end{array}$ & -- & $\begin{array}{c}2,617 \\
19\end{array}$ & $\begin{array}{c}306 \\
23^{* *}\end{array}$ & -- & $\begin{array}{l}375 \\
95\end{array}$ & $\begin{array}{l}222 \\
298^{N S}\end{array}$ \\
\hline $\begin{array}{l}1983 \text { clipping vs. } \\
1983 \text { burning }\end{array}$ & $\begin{array}{c}2,360 * \\
908\end{array}$ & $\begin{array}{l}3,250 \\
2,028\end{array}$ & $\begin{array}{l}327 \\
213^{*}\end{array}$ & $\begin{array}{l}465 \\
427^{N S}\end{array}$ & $\begin{array}{l}297 \\
264^{N S}\end{array}$ & $\begin{array}{l}230 \\
149\end{array}$ \\
\hline $\begin{array}{l}1983 \text { burning vs. } \\
1984 \text { burning }\end{array}$ & -- & $\frac{2,028}{23}$ ** & $\frac{213}{14}$ ** & -- & $\begin{array}{l}264 \\
507\end{array}$ ** & $\begin{array}{l}149 \\
299^{*}\end{array}$ \\
\hline $\begin{array}{l}\text { April } 1983 \text { burning } \\
\text { followed by Atrazine } \\
\text { vs. Atrazine }\end{array}$ & -- & $\begin{array}{l}77 \\
19^{\mathrm{NS}}\end{array}$ & $\frac{22}{23} \mathrm{NS}$ & -- & $\frac{302}{95}$ * & $\begin{array}{l}163 * \\
298\end{array}$ \\
\hline $\begin{array}{l}\text { Atrazine vs. } \\
1984 \text { burning }\end{array}$ & -- & ${ }_{23}^{19} \mathrm{NS}$ & $14^{23}$ & -- & ${ }^{95} 5^{\star \star \star}$ & $\begin{array}{l}298 \\
299^{N S}\end{array}$ \\
\hline
\end{tabular}


Table 2. Standing crops $\left(\mathrm{g} / \mathrm{m}^{2}\right)$ of Japanese brome and western wheatgrass in July 1983, 1984 and 1985, after treating in 1983 and/or 1984. Badlands National Park, South Dakota

\begin{tabular}{|c|c|c|c|c|c|c|}
\hline \multirow[b]{2}{*}{ Contrast } & \multicolumn{3}{|c|}{ Japanese brome } & \multicolumn{3}{|c|}{ Western wheatgrass } \\
\hline & 1983 & 1984 & 1985 & 1983 & 1984 & 1985 \\
\hline $\begin{array}{l}\text { No treatment vs. } \\
1983 \text { burning }\end{array}$ & $\begin{array}{l}75^{\star \star} \\
28^{-1}\end{array}$ & ${ }^{74} \mathrm{NS}$ & ${ }^{21} 5^{\mathrm{NS}}$ & ${ }_{90}^{88} \mathrm{NS}$ & ${ }_{33}^{106}$ NSS & $\frac{51}{35}$ * \\
\hline $\begin{array}{l}\text { No treatment vs. } \\
1984 \text { burning }\end{array}$ & -- & 74 * & $\frac{21_{\star \star}}{1}$ & -- & ${ }_{112^{\mathrm{NS}}}^{106}$ & $\begin{array}{l}51 \\
66\end{array}$ \\
\hline $\begin{array}{l}\text { No treatment vs. } \\
\text { double burning } \\
\text { (1983 and 1984) }\end{array}$ & -- & $\begin{array}{l}74 \\
24\end{array}$ & $21^{2}$ & -- & ${ }_{92}^{106} \mathrm{NS}$ & $\begin{array}{l}51 \\
36\end{array}$ \\
\hline $\begin{array}{l}1984 \text { burning vs. } \\
\text { double burning } \\
\text { (1983 and } 1984 \text { ) }\end{array}$ & -- & $24^{4} \mathrm{NS}$ & $\frac{1}{2} \mathrm{NS}$ & -- & ${ }_{92}^{112} \mathrm{NS}$ & $\begin{array}{l}66 \\
36\end{array}$ \\
\hline $\begin{array}{l}\text { No treatment vs. } \\
\text { Atrazine } \\
\text { (Sept. 1983) }\end{array}$ & -- & $0^{74}$ ** & $\frac{21_{\star \star *}}{1}$ & -- & ${ }_{39}^{106} \mathrm{NS}$ & $\frac{51}{65}$ * \\
\hline $\begin{array}{l}1983 \text { clipping vs. } \\
1983 \text { burning }\end{array}$ & $\begin{array}{l}47 * \\
28\end{array}$ & ${ }_{100^{\mathrm{NS}}}^{124}$ & ${ }_{15}^{23} \mathrm{NS}$ & ${ }_{90}^{80} \mathrm{NS}$ & $33^{65}$ & $\frac{42}{35^{\mathrm{NS}}}$ \\
\hline $\begin{array}{l}1983 \text { burning vs. } \\
1984 \text { burning }\end{array}$ & -- & $100^{* \star}$ & $1^{15}$ * & -- & $112^{33}$ & $\begin{array}{l}35 \\
66\end{array}$ \\
\hline $\begin{array}{l}\text { April } 1983 \text { burning } \\
\text { followed by Atrazine } \\
\text { vs. Atrazine }\end{array}$ & -- & ${ }_{0}^{8} \mathrm{NS}$ & $1^{1}$ & - & ${ }_{39}^{87} \mathrm{NS}$ & $65^{33}$ \\
\hline $\begin{array}{l}\text { Atrazine vs. } \\
1984 \text { burning }\end{array}$ & -- & ${ }_{4}^{\mathrm{NS}}$ & $1^{1}$ & -- & $112^{39} \mathrm{NS}$ & ${ }_{66}^{65} \mathrm{NS}$ \\
\hline
\end{tabular}




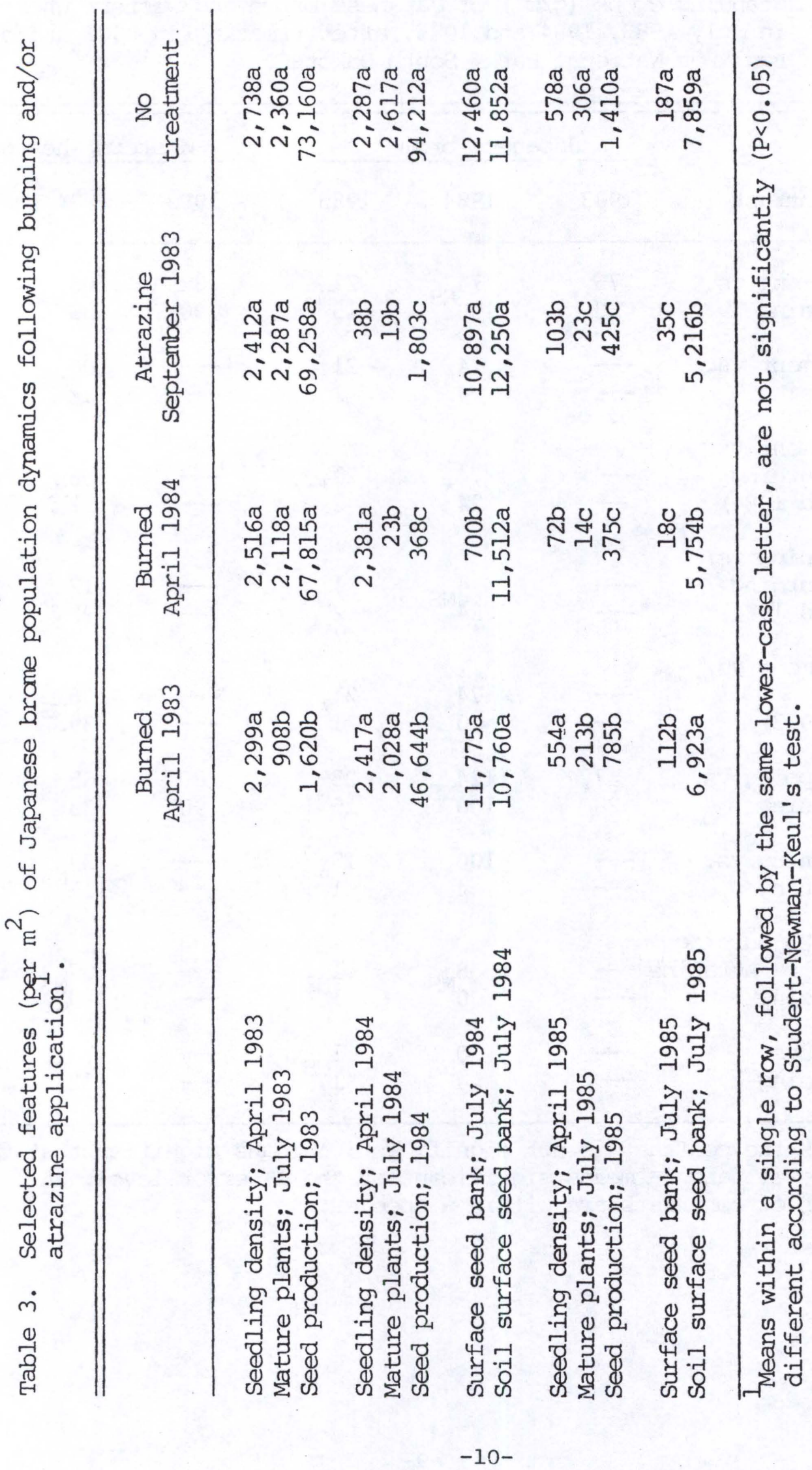


occurred. Preemergent applications of atrazine reduced Japanese brome density for two years and western wheatgrass density for one year.

Carryover of Japanese brome seed in the seed bank was sufficient to establish populations similar to untreated plots in the next generation following a spring fire if sufficient soil moisture was available. Since many of the seeds germinating in the fall are from the previous year's seed crop (Baskin and Baskin 1981), the loss of a single seed crop may not affect the next year's population. No reductions in post-burned generations of Japanese brome were observed in this study until the dry 1985 growing season. Some Japanese brome seeds are destroyed by spring burning but the seed bank appears to have sufficient reserves to renew the population in the next generation.

Spring burning, in this study, only significantly affected the generation of annual plants being burned. Subsequent generations were not significantly affected until a drier year was encountered. As a result, spring burning cannot be considered a suitable method of controlling Japanese brome in western wheatgrass communities. Atrazine has a carryover influence on subsequent generations for at least two years. Atrazine damage to western wheatgrass was significant for only one year. Western wheatgrass standing crop increased during the second growing season after atrazine application.

\section{Literature Cited}

Baskin, J. M. and C. C. Baskin. 1981. Ecology of germination and flowering in the weedy winter annual grass Bromus japonicus. J. Range Manage. 34:369-372.

Evans, R. A. and J. A. Young. 1984. Microsite requirements for downy brome (Bromus tectorum) infestation and control on sagebrush rangelands. Weed Sci. 32 (supplement 1): 13-17. 